\title{
Building a prospective participatory approach for long-term agricultural sustainability in the Lezíria do Tejo region (Portugal)
}

\section{Construire une approche participative en géoprospective pour établir un développement agricole durable dans la région de Lezíria do Tejo (Portugal) \\ Construcíon un dispositivo de geoprospectivo de participación para instalar un desarrollo agrícola sostenible en la región de Lezíria do Tejo (Portugal)}

\author{
Patrícia ABRANTES, Margarida QUEIRÓS, Guilhem MOUSSELIN, Claire \\ RUAULT, Étienne ANGINOT et Inês FONTES
}

Volume 60, numéro 170, septembre 2016

Prospective territoriale participative

Version originale soumise en mars 2016. Version révisée reçue en janvier 2017.

URI : https://id.erudit.org/iderudit/1040537ar

DOI : https://doi.org/10.7202/1040537ar

\section{Aller au sommaire du numéro}

Éditeur(s)

Département de géographie de l’Université Laval

ISSN

0007-9766 (imprimé)

1708-8968 (numérique)

Découvrir la revue

Citer cet article

ABRANTES, P., QUEIRÓS, M., MOUSSELIN, G., RUAULT, C., ANGINOT, É. \& FONTES, I. (2016). Building a prospective participatory approach for long-term agricultural sustainability in the Lezíria do Tejo region (Portugal). Cahiers de géographie du Québec, 60(170), 303-323. https://doi.org/10.7202/1040537ar
Résumé de l'article

Abordant la question des écarts entre théorie, recherche et pratique, cet article examine une démarche hybridant recherche-action participative, géoprospective et système d'information géographique (SIG) participatif. Cette démarche regroupe des acteurs de terrain, des acteurs politiques et des chercheurs, dans une région agricole périurbaine du Portugal, la Lezíria do Tejo, afin d'anticiper les changements possibles des territoires agricoles, en tenant compte des dynamiques spatiales. Nous utilisons une méthode en quatre étapes qui intègre à la fois des approches quantitatives et qualitatives, pour sélectionner les zones d'enquête et identifier les intérêts des parties prenantes. L'objectif de notre démarche associée à l'établissement de scénarios à long terme est d'encourager les actions en faveur de solutions pour une agriculture durable dans cette région. Les résultats mettent en lumière toute la pertinence des approches participatives - à l'instar de celle développée dans cet article - pour éclairer les prises de décisions des différentes catégories d'acteurs. En effet, ces démarches aident à dissiper les méfiances entre acteurs, renforcent la cohésion communautaire et amènent à bâtir des solutions communes à partir de visions différentes. Fondé sur une approche de recherche-action participative, ce travail contribue à réduire le fossé entre le monde académique et le monde opérationnel, révélé par la volonté des professionnels eux-mêmes de participer aux avancées de la recherche. 


\title{
Building a prospective participatory approach for long-term agricultural sustainability in the Lezíria do Tejo region (Portugal)
}

\author{
Construire une approche participative \\ en géoprospective pour établir un \\ développement agricole durable dans la \\ région de Lezíria do Tejo (Portugal) \\ Construcion un dispositivo de \\ geoprospectivo de participación para \\ instalar un desarrollo agrícola sostenible en \\ la región de Lezíria do Tejo (Portugal)
}

\author{
Patrícia ABRANTES et Margarida QUEIRÓS \\ CEG, IGOT, Universidade de Lisboa, Portugal \\ Patricia.Abrantes@campus.ul.pt \\ Margaridav@campus.ul.pt \\ Guilhem MOUSSELIN, UMR CNRS 5319 Passages, \\ Université Bordeaux Montaigne, France \\ G.Mousselin@gmail.com \\ Claire RUAULT, GERDAL, La Houdinais, France \\ C.Ruault.Gerda|@wanadoo.fr \\ Étienne ANGINOT, LEADER France, France \\ Eapro@wanadoo.fr \\ Inês FONTES, CEG, IGOT, Universidade de Lisboa, \\ Portugal \\ Inescsfontes@campus.ul.pt
}

\begin{abstract}
Addressing the gaps between theory, research and practice, this paper explores a hybrid mindset of participatory action research (PAR), geoprospective and participatory geographical information system (PGIS). This approach brings together stakeholders, policy-makers and researchers - in an agricultural peri-urban region of Portugal, the Lezíria do Tejo region - to anticipate the possible changes in agricultural territories, while taking spatial dynamics into account. It uses a four-step methodology which integrates qualitative and quantitative approaches to select stakeholders' interview areas, implement prospective workshops to engage and explore the stakeholders' interests and encourage actions towards finding solutions for long-term agricultural sustainability in this region. The results from our study highlight that more participative approaches such as the ones developed here must be implemented towards decision-making, since they help to dispel the distrust between stakeholders, strengthen community cohesion and also contribute to build common solutions drawing upon various perspectives. From a PAR perspective, this work contributes to bridge the gap between academia and practitioners, as is shown by a willingness of the practitioners to actively participate in the research under progress.
\end{abstract}

\section{Keywords}

Participatory action research (PAR), geoprospective, geographic information, scenario, Portugal, sustainable agriculture.

\section{Résumé}

Abordant la question des écarts entre théorie, recherche et pratique, cet article examine une démarche hybridant recherche-action participative, géoprospective et système d'information géographique (SIG) participatif. Cette démarche regroupe des acteurs de terrain, des acteurs politiques et des chercheurs, dans une région agricole périurbaine du Portugal, la Lezíria do 
Tejo, afin d'anticiper les changements possibles des territoires agricoles, en tenant compte des dynamiques spatiales. Nous utilisons une méthode en quatre étapes qui intègre à la fois des approches quantitatives et qualitatives, pour sélectionner les zones d'enquête et identifier les intérêts des parties prenantes. L'objectif de notre démarche associée à l'établissement de scénarios à long terme est d'encourager les actions en faveur de solutions pour une agriculture durable dans cette région. Les résultats mettent en lumière toute la pertinence des approches participatives - à l'instar de celle développée dans cet article - pour éclairer les prises de décisions des différentes catégories d'acteurs. En effet, ces démarches aident à dissiper les méfiances entre acteurs, renforcent la cohésion communautaire et amènent à bâtir des solutions communes à partir de visions différentes. Fondé sur une approche de recherche-action participative, ce travail contribue à réduire le fossé entre le monde académique et le monde opérationnel, révélé par la volonté des professionnels eux-mêmes de participer aux avancées de la recherche.

\section{Mots-clés}

Recherche-action participative, géoprospective, information géographique, scénario, Portugal, agriculture durable.

\section{Resumen}

En este artículo se analiza un proceso que combina la investigación-acción participativa, la geoprospectiva y sistemas de información geográfica (SIG), tratando así la diferencia entre teoría, investigación y práctica. Este dispositivo reúne agentes de terreno, políticos e investigadores en una región agrícola periférica de Lezíria do Tejo, Portugal, para anticipar los cambios posibles en los territorios agrícolas y considerando las fuerzas espaciales. Se utiliza un método en cuatro etapas con el fin de integrar enfoques cuantitativos y cualitativos, de seleccionar las zonas para la encuesta y de determinar los intereses de las personas concernientes. El objetivo, conjunto a la proposición de escenarios de largo plazo, consiste en apoyar acciones favorables a resoluciones para una agricultura sostenible en la región. Los resultados hacen resaltar la pertinencia de los dispositivos de participación para alumbrar la toma de decisión de los diferentes protagonistas. Tal proceso ayuda a disipar la desconfianza entre los participantes, refuerza la cohesión colectiva y permite soluciones comunes a puntos de vista divergentes. El trabajo de investigación-acción participativa contribuye a reducir el abismo entre el mundo académico y el operacional indicado por los profesionales deseosos de participar al progreso de la investigación.

\section{Palabras claves}

Investigación-acción participativa, geoprospectiva, información geográfica, escenario, Portugal, agricultura sostenible.

\section{Introduction}

Agriculture in a peri-urban context plays a fundamental role in ensuring the local food supply and urban-rural linkages. In recent years, particular attention has been paid to its function as an ecosystem service provider (Power, 2010; Van Zaten et al., 2014). However, agriculture in peri-urban environments faces several threats, such as pressure from urban encroachment (Poulot, 2008; Balez and Reunkrilerk, 2013; Padeiro, 2015) and farmland abandonment, unsustainable intensification of land use, pollution and, more generally, climate change (Abelairas-Etxebarria and Astorkiza, 2012; Abrantes et al., 2013, 2016). These issues may undermine its sustainability over time (EEA, 2006). Several authors consider that preserving and boosting sustainable 
agriculture in peri-urban areas is an important challenge for territorial development and spatial planning and that it must involve new interactions between local stakeholders and new multilevel governance mechanisms (Vandermeulen et al., 2006; Leck and Simon, 2013; Mercier et al. , 2014). Moreover, establishing a link between researchers and practitioners could foster engagements to support agricultural sustainability in these particular complex territories (Bourgeois, 2013).

Participatory processes, such as participatory action research (PAR), empower communities through research and thus contribute to catalyze social change. PAR is a model created for community development within certain social contexts (especially in rural areas) and aims to take actions towards better living conditions (Katoppo and Sudradjat, 2015). For instance, Sutherland et al. (2006) show the success of PAR in identifying one hundred ecological questions of high policy relevance in the United Kingdom. Vermeulen et al. (2012) explain how participatory research is helping policy engagements on several levels to achieve food security in low-income and middle-income countries. Björklund et al. (2014) chose PAR to foster research and to develop an assessment of ecosystem services in agroforestry systems in Sweden. PAR tailors interventions towards a desired future, enabling behavioural changes at the community level, where the decisions for change come from the community members dwelling within their social environment. The researchers' and the community's position is equivalent when actions are taken. Academics and the community participants work "extensively and dependent on the practice of critical reflexive action" (Katoppo and Sudradjat, 2015: 121) and "for academics it signals a shift in approach from the abstract to the practical, from ideas to action" (Mason, 2015: 498). PAR is therefore considered a collaborative, dynamic and progressive research stage consisting of cyclical steps of planning, action, observation and results. Ultimately, it contributes to the achivement of sustainable outcomes (Kindon, 2010).

Furthermore, the use of PAR in scenario building and prospective analysis for spatial planning has received increased attention over the last decade (Bonard, 2006; Volkery et al. ,2008). Inviting stakeholders to react to a plausible set of events or to build the future events themselves helps to reinforce collective solutions and decision-making process. As Fletcher et al. (2015) demonstrate, PAR aims to formulate future scenarios (Ogilvy, 2002; De Jouvenel, 2004; Godet, 2005) and anticipates spatial change - also known as geoprospective (Houet and Gourmelon, 2014; Voiron-Canicio and Liziard, 2015).

Geoprospective belongs to the set of prospective approaches developed in the 1990s by Michel Godet (2001) that investigates the future of territories by using an approach that assumes that the future is not simply an extension of past events as there may be several plausible futures (Voiron-Canicio and Liziard, 2015). Furthermore, it gives special attention to the spatial dimension, focusing on how space reacts to specific events or actions. Indeed, a geoprospective process happens through the interaction of communities and stakeholders by the consideration of spatial structures and a capacity to perceive creatively what is happening in their environment and imagine its implication (Voiron-Canicio and Liziard, 2015). According to Mason (2015), one way to find out how communities feel about their environment and how they perceive their territory is to conduct interviews to obtain information on expectations, fears and values. Interviews also help to uncover power dynamics and to highlight the practices that are embedded in place. Surveys and interviews are some of the most relevant tools of research in order to find how communities perceive their territories and imagine 
the future land use; for instance, how individuals interact with the territory through their agricultural practices and possible land use changes (e.g., farmland disappearing as a result of urban development). Maps and scenarios can be built using the data and validated by the participants during the PAR process.

The growth of geographic information systems (GIS) and the increased use of geographic information (GI) has been facilitating this kind of qualitative approach (i.e., helping to explore and develop convincing scenarios and tackling territorial complexity) (Debarbieux and Lardon, 2003; Brown et al., 2012; Gourmelon et al., 2012; Hewitt et al., 2014; Grémont and Houet, 2015; Hung et al., 2016). Several authors have argued that GI and participatory GIS (PGIS) encourage interaction between people who consult and observe spatial representations, those analyzing and questioning these spatial representations and finally those making decisions. This process allows territorial knowledge to be shared and stimulates collective debate on strategies and territorial visions that may be complementary. PGIS have been criticized for the difficulties in incorporating non-cartographic information or when a core component of the method strongly depends on the intensive use of computer technologies and skills, which makes it difficult for people to interact with them. However, PGIS are flexible enough to create diverse visual representations of places and communities. They also help explain, argue and facilitate the negotiation process between stakeholders, especially in the field of spatial planning (Elwood, 2006; Kindon 2010).

In the Portuguese context, linking multilevel governance mechanisms and PAR (e.g., by using GI) is not unusual, especially in the spatial planning process. Spatial planning instruments such as the National Policy Program and the Regional Plans or even strategic plans, usually make use of participative tools in the framework of the existing public policy governance structures (Queirós, 2007). However, criticism of participative models in Portugal emphasizes the general lack of interest of the public, coupled with weak dissemination strategies, which hinders the engagement of the inhabitants that should be directly involved (Pinto, 2011). Moreover, there is still some distrust between local communities, stakeholders and central government entities. As is typical, there is also some separation between local communities, the universities and research projects.

In this paper, ${ }^{1}$ we present a Portuguese case study and describe the hybrid mindset of PAR, geoprospective and PGIS, meaning that qualitative and quantitative methods were used to anticipate the possible changes of territories and to help shape visions and solutions for long-term agricultural sustainability. The research purpose was to demonstrate the relevance of anticipating the future of agriculture in peri-urban territories, taking into account land use changes (e.g., widespread urbanization, land abandonment and reforestation) in a sustainable development perspective. Therefore, some questions needed to be answered: How can researchers engage so many different stakeholders in a vast region such as Lezíria do Tejo? Can researchers, communities and stakeholders anticipate the consequences of possible land use changes for agriculture? How can we link research findings and the stakeholders' suggestions

1 The research was conducted in the context of the international Durabilite des Agricultures Urbaines en Méditerranée/Sustainability of Urban Agricultures in the Mediterranean area (DAUME) project, aiming to build participative prospective territorial scenarios towards sustainable agro-urban systems in five Mediterranean countries (Valette et al., 2012; Soulard et al., 2015): Algeria, France, Italy, Morocco and Portugal (ANR, 2010; INRA, 2011). 
towards common solutions for the future of agriculture in the aforementioned region? In order to answer these questions, we used GI and PAR to select particular interview sites and participatory prospective workshops, since they both support land use scenario building. Moreover, by working together with stakeholders and the community in the construction of common visions for the future of agriculture, this research aimed to highlight the relevance of geoprospective, in other words, prospective studies taking spatial structures and dynamics into account.

\section{Methodology}

\section{Study area}

The Lezíria do Tejo region is a statistical sub-region (NUTS III) with about 247,000 inhabitants (INE, 2011). Territorially, it corresponds to an ancient unit called "Ribatejo" (upper Tagus). The Lezíria do Tejo region is located on the West Coast of the Iberian Peninsula, near the Lisbon metropolitan area, and it extends over 4,275 $\mathrm{km}^{2}$ on both sides of the Tagus River (Figure 1). It is composed of 11 municipalities, where Santarém is the main city with about 61,700 inhabitants. Other urban centres play an important role in the regional urban system, such as Rio Maior (21,192 inhabitants), Almeirim (23,376 inhabitants) and Cartaxo (24,462 inhabitants) (INE, 2011). According to the Portuguese Census, the region gained 25,000 new residents between 1960 and 2011 and over 14,500 between 1991 and 2011. These population dynamics are reflected in increasing soil sealing and land use fragmentation. In 2006, according to CORINE Land Cover database (CLC), approximately $117 \mathrm{~km}^{2}$ were built-up areas (3\% of the territory), the agricultural area was 2,008 $\mathrm{km}^{2}(47 \%)$ and the forest area covered 2,080 $\mathrm{km}^{2}$ (49\%). Between 1990 and 2011, $59 \mathrm{~km}^{2}$ of natural areas, including $33 \mathrm{~km}^{2}$ of farmland, turned into built-up areas (DGT, 2006).

Agriculture and food processing industries play a fundamental role in the region's economy, with 9,643 farmers, representing a percentage well above the national average (7\% versus $2 \%$ ) (INE, 2011). This agricultural context is also reflected in a dynamic network of agricultural stakeholders (associations of small farmers and businessmen and rural development associations). The region mainly produces horticulture (e.g., tomatoes, melons, strawberries), wine, olive oil, rice and livestock. However, despite the relevance of agriculture in the region, the number of farms, agricultural population and utilized agricultural areas have all suffered a general decline between 1999 and 2009. This is especially true on the northern banks of the Tagus River, where small farmers and small properties are no longer as relevant in the economic profile (Abrantes et al., 2013). 
Figure 1 Study area and artificial land cover

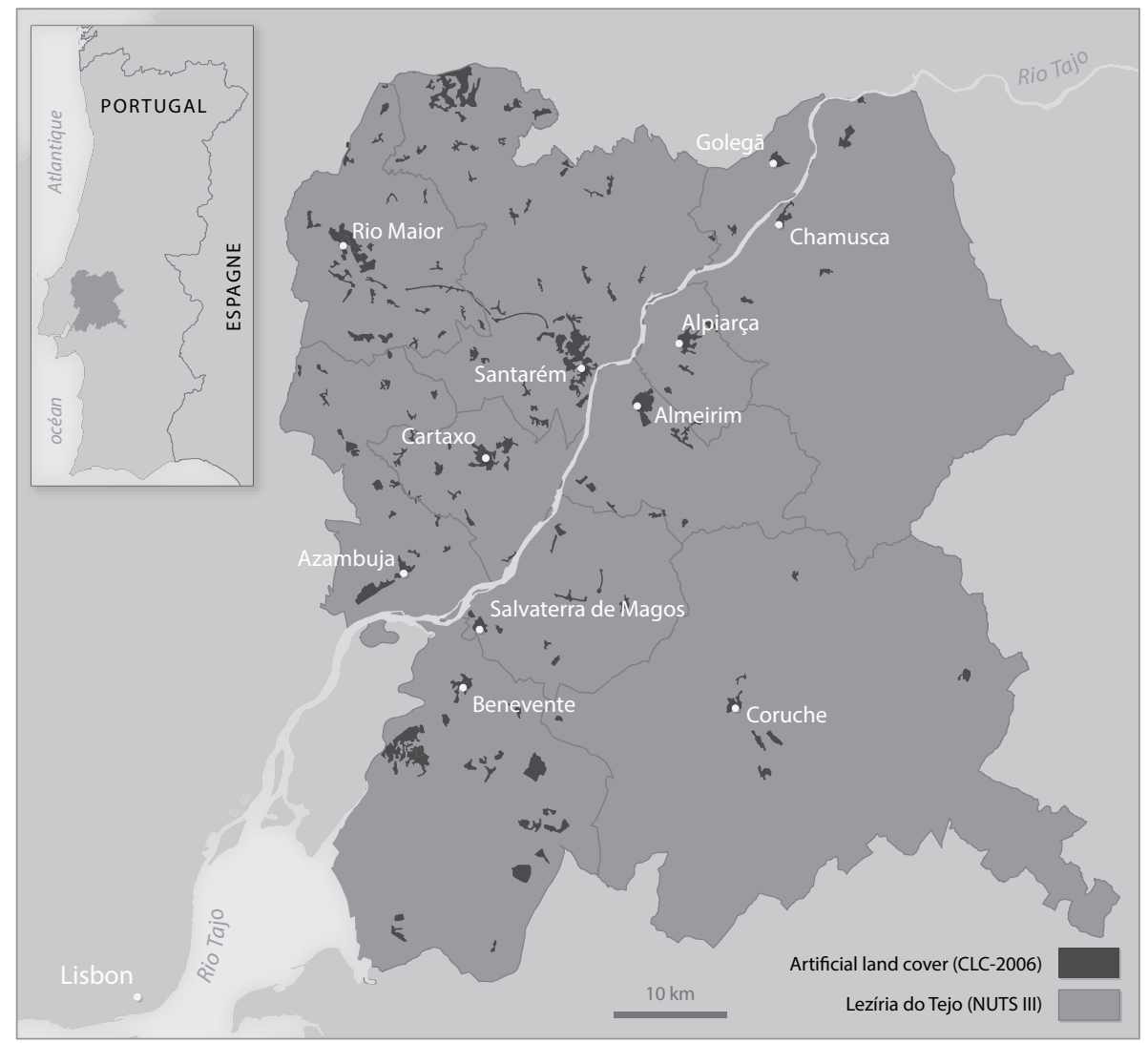

Conception: Abrantes, Queirós, Mousselin, Ruault, Anginot and Fontes, 2015

Source: DGT, 2006; 2015

\section{Data and methods}

In methodological terms, PAR takes into account spatial structures and dynamics to formulate future scenarios (geoprospective) and is composed of four steps:

1. Selecting case studies where interviews were held with local stakeholders (farmers and rural development associations, local and regional policy-makers and spatial planning technicians). These interviews enabled the researchers to diagnose issues and challenges for the future and to build thematic questions to be dealt with in two local participatory prospective workshops, while also contributing to establish trust with the stakeholders by understanding their needs and aspirations, interests and actions;

2. Promoting two workshops with the participation of interviewees and also of the general public, with the aim to debate how the stakeholders perceive land use change and the future of agriculture in the region and what solutions for the future they present;

3. Interpreting results. In this stage, researchers produced a synthetic matrix, while also proposing three land use quantitative scenarios to further enhance discussions, debates and proposals towards policy-making in a final seminar with the participation of the stakeholders;

4. Validating results and discussion. 
This four-step approach made intensive use of GI, spatial modelling and analysis to identify case studies (step 1) and to build land use scenarios (step 3). In parallel, a sociological approach was employed in the interviews using a co-active approach (Ruault, 1996; Darré, 2006) (step 1) and in the workshops (step 2).

\section{Selected case studies and interviews with stakeholders}

Even though this vast region has a strong sense of unity related to rurality and agriculture and is very culturally attached to its capital (Santarém), the study area is too large and heterogeneous to be studied using the referred methodology. Hence, the research interwove several types of GI to define smaller case studies where interviews could take place. The geographic database was composed of three types of information: networks of actors, land cover changes and agricultural dynamics.

The networks of actors consist of a geodatabase containing all the interconnected agricultural actors of the region. Connections can be economic and socio-cultural (Morgado et al., 2014; Abrantes et al., 2012). The parishes with the largest number of connected actors (Figure 2a) were extracted. Subsequently, in order to determine where major agricultural to urban land use changes have occurred, two Portuguese land occupation maps from 1990 and from 2006 were cross-analyzed. The parishes that grew above average ( $>2 \%$ ) were also extracted (Figure $2 \mathrm{~b}$ ). Three statistical variables related to agricultural dynamics (number of farms, utilized agricultural area and number of farmers) were analyzed and the parishes where all these variables registered a decline above 50\% (Figure 2c) were chosen. Finally, the maps were overlaid and parishes were chosen where at least two of those variables were superimposed. These parishes were: Achete and Póvoa de Santarém in the municipality of Santarém; Fazendas de Almeirim, Benfica do Ribatejo and Almeirim, in the municipality of Almeirim and Santo Estevão in the municipality of Benavente (Figure 2d).

After selecting the interview sites, 34 formal in-depth interviews, ranging from 1 to 3 hours, were conducted between the end of 2012 and 2013 with farmers ( $n=25$ ); farmers unions and associations ( $n=5)$; spatial planning technicians and policy-makers $(n=3)$. Semi-structured interviews registered by field notes and recordings were conducted in order to achieve a deeper understanding of the interviewees' point of view, highlighting the agricultural dynamics and the diversity of the forms of agriculture that coexist in this region. The interviews also questioned the future of agricultural activities and their interactions. The interviews were structured around two different guidelines. The first, relating to farmers, was organized in five axes: 1) presentation and characterization of the farm (location and distance to major urban centres, type of farm, labour force, characteristics, technical and economic orientations, farming technical procedure [rotation systems, use of machinery, etc.] and other activities [commercialization, tourism, etc.]); 2) difficulties encountered, problems and capabilities (appreciation of the consequences of urban proximity); 3) issues and challenges for the future (identification of changes that occurred in recent years in farmland and their impact on the farmer's activity and the interviewee's visions for the future of local and regional agriculture); 4) relations with agricultural and non-agricultural actors (cooperation or partnership between farmers, relations between farmers and residents, technical and political relations); 5) future of agriculture (projects, innovations, etc.). 
Figure 2 GIS overlay analysis of networks of actors, agriculture to urban land cover changes, decreasing agricultural dynamics and selected interview sites
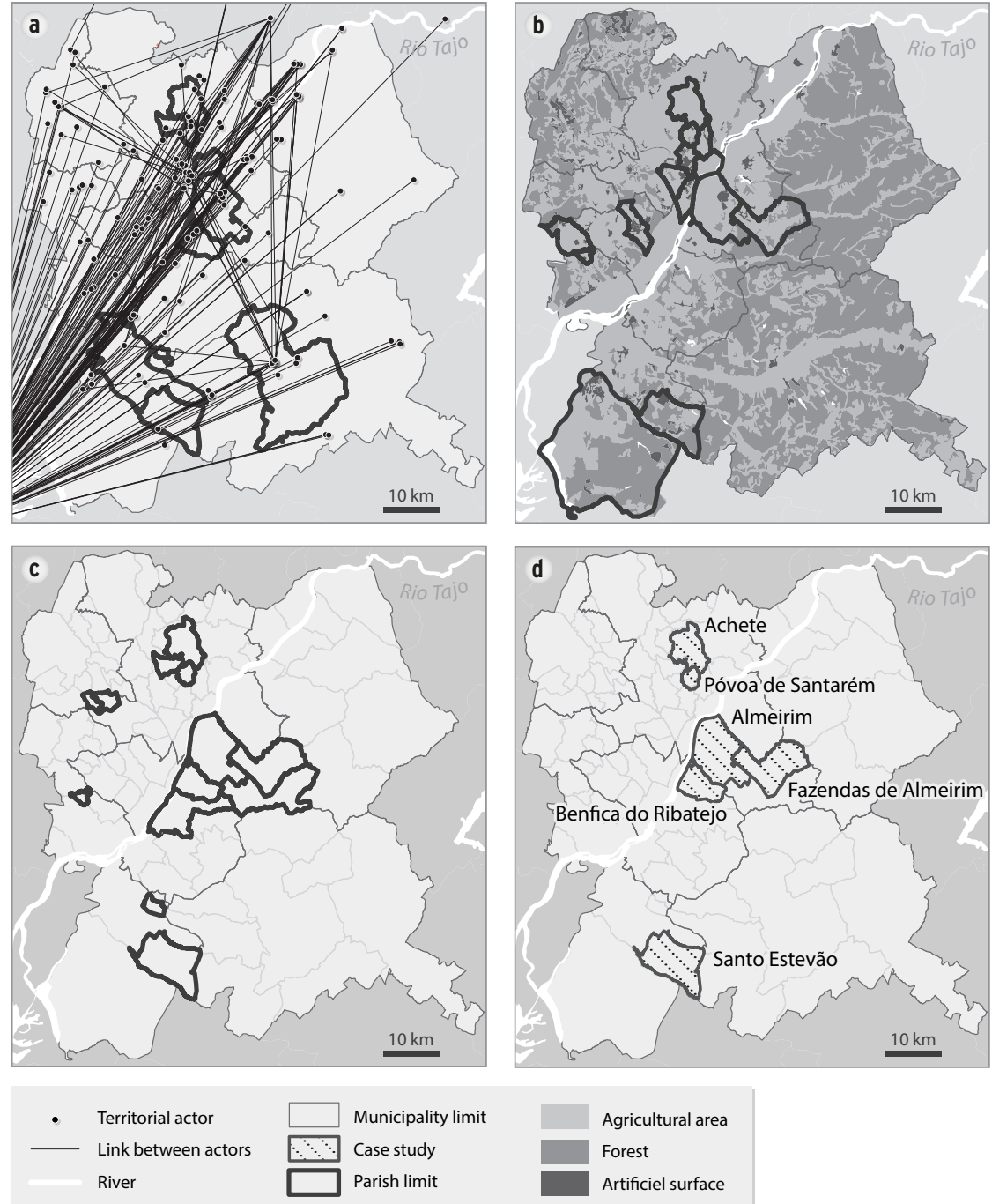

Conception: Abrantes and Fontes, 2015

Source: a) DGT, 2015 b) DGT, 2006; 2015 c) INE, 1999; 2009; DGT, 2015 d) DGT, 2015

The second guideline, for technicians and policy-makers, was also divided into five main points: 1) presentation of the organization (main activities, sectors of intervention, funding sources, etc.) and the program (origin, objective, target audience, etc.); 2) agriculture related activities (actions taken with farmers, forms of mobilization, etc.); 3) difficulties encountered, problems and capabilities; 4) relations with agricultural and institutional actors (projects with farmers and institutional partnerships and their goals); 5) issues and challenges for the future (identification of changes that occurred in the agricultural sector and in the region). 
This analysis, which started with the stakeholders' perspectives, enabled us to understand the path towards agricultural sustainability, by giving us an insight into the factors that the interviewees expect to condition and/or boost the future of that activity. Additionally, it provided the opportunity for the interviewer/researcher to gain more insight on non-consensual issues that divided the stakeholders.

The interviews were then analyzed by the researchers using content analysis techniques (interpretative, explanatory and critical) to filter and group problems and challenges and transform them into questions. Those questions were then to be discussed together with the stakeholders in a future event: a participatory prospective workshop.

\section{Participatory prospective workshops}

Two participatory prospective workshops on the topic "The future of agriculture in our area, problems and prospects" were held in June 2014, with the purpose of integrating the knowledge produced in the interviews. Critical problems and challenges identified by the stakeholders during the interviews were transformed by the researchers into eight main questions to be debated during the workshops. The workshops also brought the opportunity to discuss alternative solutions and policies to be implemented and find options to deal with those key issues.

The first workshop took place in Almeirim and included local stakeholders, namely interviewed farmers from the parishes of Almeirim, Fazendas de Almeirim, Benfica do Ribatejo and Santo Estevão. The second workshop was held in Achete (a Santarém municipality), representing stakeholders of the parishes of Achete, Póvoa de Santarém and Azoia de Baixo. In both workshops, municipality and inter-municipality policy-makers and spatial planning technicians, as well as regional agricultural officers were invited to join the debate. Additionally, the workshops were open to all local citizens who wished to participate.

The stakeholders that had participated in the interviews were formally invited by mail, while public announcements about the workshops were posted in public places and on social networking websites, in hopes of opening the debate to a larger group.

There were 12 participants in Almeirim. Three farmers participated: a wine and strawberry producer, also representing a wine cooperative, a farmer from a wine company and a cattle farmer. One officer of the regional agriculture department, one spatial planner from the Lezíria do Tejo inter-municipality, two other technicians from Almeirim municipality and five Sustainability of Urban Agricultures in the Mediterranean area (DAUME) project researchers also participated in the workshop. In Santarém, there were eleven participants: six farmers (one olive oil producer, one cereal producer and four organic producers), one of the farmers was also representing a rural development association; one officer of the regional agriculture department and four researchers. The lack of representation over the total farmer's population in the region is low (in Santarém, there are 256 farmers, in Almeirim and in Benavente, 62 (INE, 2009). This underrepresentation and the issues that come from it will be discussed later.

Both workshops lasted three hours and included a brief 30-minute digital presentation that showed a map with the selected case studies and the main spatial dynamics occurring in those areas and, also, the interview results highlighting the main questions identified by the researchers from the analysis of the interviews. These questions were also displayed on paperboards by the researchers monitoring the debate in both workshops (Figure 3). 
Figure 3 Workshop in Achete, Santarém

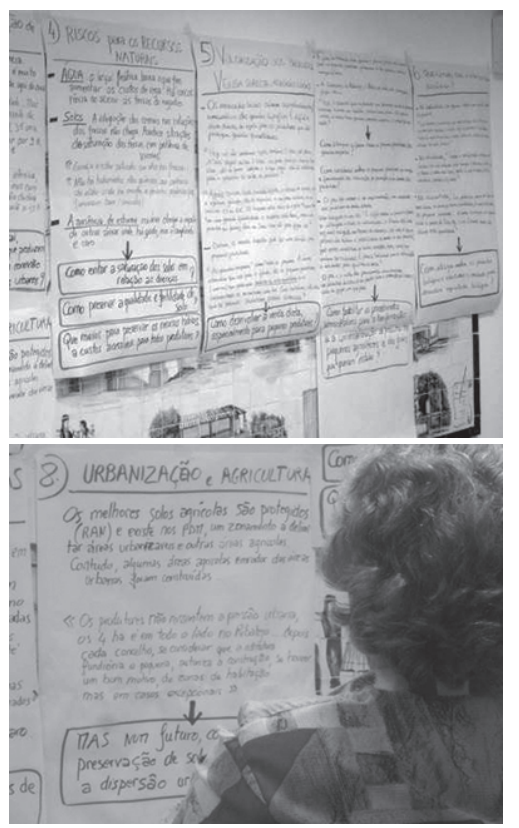

Source: Assumpção, 2014

Afterwards, there was time for a debate triggered by two questions: whether the participants agree with the main questions and what supplements, modifications or clarifications can be added to the former presentation. Then, after explaining certain issues and clarifying a few points, the participants exchanged opinions, shared arguments, points of view and elaborated a diagnosis of the agricultural situation in the region. At the end, researchers made a synthesis of the discussed issues and continued the prospective analysis with the stakeholders by asking: What can we do in the future to answer the main issues regarding agriculture and how? With whom? What proposals and strategies should be employed? The synthesis was created by writing the questions on the paperboard and a full transcript of the debate was also carried out to support further analysis.

\section{Interpreting the results and building land use and land cover scenarios}

After the workshops, the researchers analyzed all the results and reflected on them. A synthetic matrix was built in order to link and synthesize the key questions and the stakeholders' solutions. This matrix was an important step in transforming the stakeholders' challenges into quantitative land use scenarios and thus give a spatial dimension to questions/solutions.

However, at this stage, not every stakeholder's challenge could be transformed into a land use scenario due to their non-spatial character. Researchers defined three scenarios: 1) business as usual (BAU);2) climate change: Stakeholders considered that crop systems are changing and that extreme weather conditions have impacted those systems. For example, what are the impacts on land use if the temperature go up by $2^{\circ} \mathrm{C}$ ? 3) local production: Stakeholders considered that it is important to value small-circuit chains and diversify their activities to increase agricultural competitiveness in the region. However, productive land is scarce. What are the impacts on land use if we increase the utilized agricultural area, the number of small farmers and diversify agriculture?

The scenarios were built by using Multilayer Perceptron (MLP) from neural network and Cellular Automata (CA) methods (Morgado et al., 2014), based on land use data from two periods $(1990,2006)$ and a list of 22 socio-economic and demographic variables. A statistical and a GIS software were both used (STATISTICA and IDRISI Taiga). The first objective was to train a set of MLPs networks for each scenario to have a land use cover matrix transition from 1990 to 2006. For this stage, several transition rules were defined by the user (e.g., prohibition for built-up areas to grow in national reserves, among others) to obtain a matrix based on probabilities for change. Then, the matrix was inputted in the CA to determine where land use changes were located (Abrantes et al., 2016). 


\section{Results and discussion}

\section{Four topics arising from the interviews}

Despite the different territories (e.g., larger properties in Almeirim and Benavente when compared with Santarém; Almeirim is more specialized in wine production and Santarém in olive groves, while rice, livestock and cork are Benavente's mains productions), when comparing the interview results, we observed that the problems and challenges are mostly the same and that the stakeholders' opinions are convergent.

In fact, previously collected interviews showed that in recent years, there has been a growing interest in agriculture and a revalorization of the farmers' statute, with young farmers establishing in the region. There has also been a growing interest in selling in local markets. In addition, agricultural stakeholders seem to be better organized to access European funds. Nonetheless, several challenges remain to be met, according to the stakeholders' point of view. Researchers have organized them into four main topics: agricultural production; commercialization; natural resources and climate change and land use access and management.

Regarding agricultural production, the stakeholders consider that the main production of this region - horticulture - is a fragile business heavily dependent on European Union funds or national grants, relying on international markets and with major investments in producing large quantities that are generally absorbed by hypermarket chains. Horticulture entails high production costs and difficulties for those who want to produce small quantities and directly place their products in the market. In the particular case of wine production in Almeirim, small farmers complain that it is not profitable to sell to cooperatives and that other alternatives are needed. In Santarém, the three farmers that breed livestock claim that production costs are too high and that available land for this activity is also a problem, pointing out that they intend to abandon this traditional activity. Other small-scale olive oil producers argued that there is an intensive overproduction in the region which is brought on by hypermarkets with which they cannot compete, since the costs of mechanization and the need for space would increase their overall cost.

Local markets are no longer a viable option for commercialization due to the competition from large grocery stores, although, more recently, a new consumer attitude has been pushing for their resurgence. This is strongly associated with the demand for higher product quality. Ten farmers, especially the ones with smaller productions, pointed out that small chain stores and direct sales are an alternative for those producing small quantities, but the legislation that applies to transformation and direct sales is complicated. They believe that producers and local development associations could play a more supportive role on this issue.

From the natural resources and climate change perspective, two main challenges were pointed out concerning natural resources: soil and water. The interviewees identified horticulture overexploitation as a cause of soil saturation, which often leads to plant disease, especially when it comes to tomato and strawberry production. Farmers usually solve these problems by using chemical fertilizers. Moreover, water tables are increasingly lower, thus rising irrigation costs. Regarding climate change, the interviewees acknowledged that the climate is changing and that they need to replace some product varieties and seasonal cultures. They also added that autumn-winter yields are increasingly affected by irregular rains and floods. 
Finally, regarding the challenges of land use access and management, farmers explained that those who wish to establish themselves in the region have trouble finding fertile soil, as it is already occupied. Also, the prices for that type of land are high, while many of the available parcels are small, dispersed and located in remote areas. The available parcels are often abandoned and occupied by unmanaged forest and bush.

\section{Workshops: Finding common solutions for the future of sustainable agriculture}

The researchers structured the topics of the interviews in the form of questions for the future to encourage discussion and build a participatory prospective process in the workshops (Table 1).

\section{Table 1 Questions discussed in the Almeirim and Achete workshops}

\begin{tabular}{l|l}
\hline Agriculture production & $\begin{array}{l}\text { 1. How can the viability of horticulture in a competitive market be ensured? } \\
\text { 2. What is the future of animal husbandry and the olive grove? } \\
\text { 3. In the wine sector, what role must cooperatives and associations play? }\end{array}$ \\
\hline Commercialization & $\begin{array}{l}\text { 4. How should small-circuit chains be valued? } \\
\text { 5. How can small farmers compete with supermarkets? }\end{array}$ \\
\hline $\begin{array}{l}\text { Natural resources and } \\
\text { climate change }\end{array}$ & $\begin{array}{l}\text { 6. How should natural resources be preserved and how should we adapt to } \\
\text { climate change? }\end{array}$ \\
\hline $\begin{array}{l}\text { Land use access and } \\
\text { management }\end{array}$ & $\begin{array}{l}\text { 7. How can we manage the land better? How can we make land available for } \\
\text { young farmers that want to establish themselves in the region? } \\
\text { 8. How can we preserve plots of land that are suitable for agriculture, but are } \\
\text { currently facing reforestation and abandonment? }\end{array}$ \\
\hline Conception: Ruault and Anginot, 2014 & \multicolumn{2}{l}{$l$}
\end{tabular}

Concerning horticulture production, a common weakness identified by the stakeholders in both workshops is that selling prices are sometimes very low and that markets are dominated by large hypermarkets. There is also a lack of information on what is produced, their amounts and distribution, and there is no guarantee of the sales that will be made or an annual fixed price chart. To mitigate these disparities, stakeholders converged on several proposals: triggering legal provisions to reduce fluctuations in prices; decreasing the payment terms of agribusinesses to farmers; restructuring existing producer organizations to increase their bargaining power and creating a database regulated by the Ministry of Agriculture to satisfy those seeking products in that area, with information on producers, products, seasonality and availability.

In relation to livestock production, no alternative solution was presented by the stakeholders (only one farmer attended the workshop). The bureaucracy, the lack of available fertile land and high production costs confirm the high risk of this activity being abandoned in the region.

Olive oil is intensively produced in the region in order to meet the demand of national and international markets, while small producers struggle to maintain competitive prices. They cannot compete with this increasing production capacity of larger producers. Alternative options include reorganizing the whole productive process and creating negotiation models.

The wine sector grew enormously in the region; however, the two wine producers, including one representing the local cooperative, think that there are improvements to be made. The wine company producer stated that innovations in the production of 
different varieties must be made to attract new markets, for instance by associating French grape varieties with Portuguese ones to expand national markets. This could prevent the loss of national grape varieties. He also mentioned that it is important to invest in various products, such as organic wine, for example, in parallel with regular production. Otherwise, both agree that farmers should be united and that the organization of the wine sector in Almeirim, for instance, should be centralized in one cooperative rather than divided in two or three, as it currently is. In the policy-makers and municipality technicians' opinion, the existing wine route of the region (a product supported by European funds) needs to be more operative in order to attract more tourists to the area. The attractiveness of the wine route would be enhanced by providing tours of vineyards and wine cellars that are open to the public and that offer a place for tourists to sleep and eat.

In relation to commercialization, all producers participating in both workshops wish to sell directly, but bureaucratization is a big issue. One of the producers asked: "How can I find ways to sell directly to local supermarkets and restaurants without these difficulties?". The demand for local products is increasing, and local small producers cannot waste this opportunity. On the one hand, the new Community Support Framework (PDR 2020) is an opportunity to support small circuits. But for that purpose, farmers together with associations must renew and redirect their selling strategies to local markets. On the other hand, concerning big hypermarket competition, one suggestion is that small producers should cooperate with large producers. For instance, they could sell one part of the products to large farmers that have contracts with supermarkets, which would be advantageous to both types of farmers, small and large alike. Occupying a "niche market" was also mentioned as part of the solution to the problems of agricultural competitiveness in Lezíria do Tejo.

When the issue of climate change came under discussion, the participants recognized the relevance of this topic. Some stated that the strawberry harvest time has changed in the region, as a result of longer summers, which has required production adaptations. Regarding soil saturation, crop rotation and using manure are recent solutions to the problem. More concerned with the overall scenario, all the organic farmers in Santarém workshop focused on the lack of seeds for the organic production of some species. The stakeholders mentioned the role of the seed bank called Colher para Semear (Spoon for Sowing) that preserves seed samples and protects them from the threats of climate change. However, the majority did not know enough about the subject.

The region faces a double problem: land abandonment and soil fragmentation on the banks of the northern Tagus River and difficulties in finding good and irrigable land on the southern river banks. During the debate, the idea of a cadastral database was presented as a possible alternative for the identification of plots with olive trees, vineyards and also abandoned land, so that farmers know where land is potentially available. This could help the establishment of economically viable agricultural farms, preventing the fragmentation and dispersion of rural property, which has long marked the region quite severely. Besides, public land stocks are a way to solve the problem of abandonment versus demand for agricultural land in the region. Regarding reforestation, there has to be better land use planning and control to avoid eucalyptus monoculture having lasting effects on the water supply. Interestingly, in a region facing urban dynamics, stakeholders do not generally perceive urban dynamics as a threat to agriculture. 


\section{Interpreting results and building land use scenarios}

After the workshops, researchers analyzed the results (i.e., categorized information), structuring critical categories of solutions for the future of agriculture in the region and their relation with regional public policies; identifying the potential factors of change and suggesting scenarios to answer the questions. They also tried presenting solutions for the territory and anticipating possible and desired changes. As outputs, a synthetic matrix and three land use scenarios were put forward. The synthetic matrix links and synthesizes key questions and the solutions the stakeholders presented in the two workshops (Table 2). Black squares represent solutions that were directly proposed by the stakeholders for a certain question, for instance, question 5: "How can small farmers compete with supermarkets?". The solution presented by the stakeholders is that small and large producers need to cooperate with each other. Grey squares are the outcome of the reflection and interpretation of the workshops' results by researchers. For instance, for the same question, a researcher found that increasing the number of associations and restructuring existing producer organizations could also be a solution for question 5. White squares show no relation in the matrix.

This matrix was an essential input to build a land use scenario and to further map particular territories where agriculture could be potentially at risk and exceeding or falling short of demand. In Figure 4, we present the mapped results for each of the three scenarios developed (BAU, climate change and local food supply), together with the reference year.

In the BAU scenario, the main changes were the percentage of non-irrigated arable land and pastures changing to permanently irrigated land (30\%). In the scenario of climate change, non-irrigated arable land, pastures and heterogeneous agricultural areas increased over permanently irrigated land that decreased consistently $(-50 \%)$. And in the local food supply scenario, permanently irrigated land and heterogeneous agricultural areas increased through the classes of non-irrigated arable land and pastures, and forest and semi-natural areas. In all scenarios, artificial surfaces increased by $2 \%$.

These results are currently being validated with each of the stakeholders that participated in both workshops. Enlarged maps of the three case studies in Almeirim, Benavente and Santarém, graphs and land use change matrices are being discussed by email and through personal meetings. Although the results are still few, their overall validation by the stakeholders is interesting even though there is some difficulty when communicating GIS and spatial analysis methods. In general, the stakeholders tended to agree more with the results presented by BAU and showed major concerns with the decline of irrigated land in the climate change scenario, for instance across the Tagus and Sorraia rivers. This is, in fact, the scenario generating more discussion and divergent positions: farmers agreeing, while policy-makers and technicians are less sure. A final workshop could enable us to show, discuss and commonly validate these results towards building a proposal aimed at further supporting the design of spatial planning for sustainable and resilient development. 


\section{Table 2 Matrix of questions and solutions achieved from the stakeholders' and researchers' interaction}

Questions raised

\begin{tabular}{|c|c|c|c|c|c|c|c|c|c|c|c|c|c|c|c|}
\hline Solutions/policies & 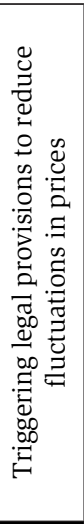 & 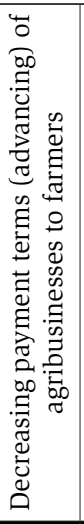 & 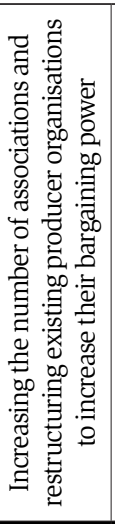 & 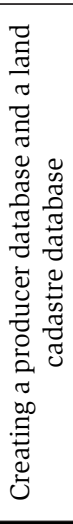 & 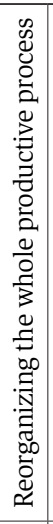 & 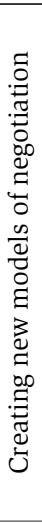 & 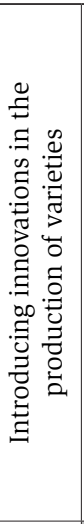 & 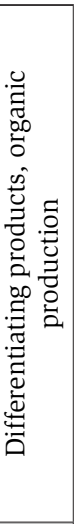 & 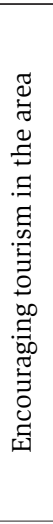 & 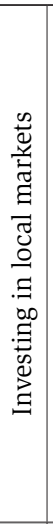 & 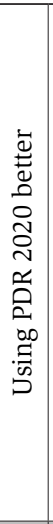 & 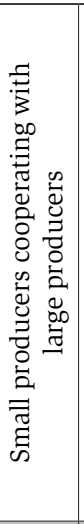 & 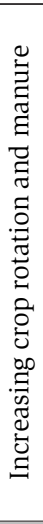 & 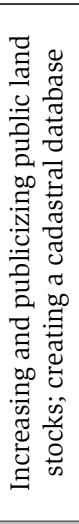 & 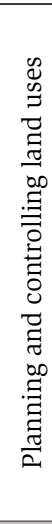 \\
\hline $\begin{array}{l}\text { 1. How can the viability of horticulture in a competitive market be } \\
\text { ensured? }\end{array}$ & & & & & & & & & & & & & & & \\
\hline 2. What is the future of animal husbandry and the olive grove? & & & & & & & & & & & & & & & \\
\hline $\begin{array}{l}\text { 3. In the wine sector, what role must cooperatives and } \\
\text { associations play? }\end{array}$ & & & & & & & & & & & & & & & \\
\hline 4. How should small-circuit chains be valued? & & & & & & & & & & & & & & & \\
\hline 5. How can farmers compete with supermarkets? & & & & & & & & & & & & & & & \\
\hline $\begin{array}{l}\text { 6. How should natural resources be preserved and how should } \\
\text { we adapt to climate change? }\end{array}$ & & & & & & & & & & & & & & & \\
\hline $\begin{array}{l}\text { 7. How can we manage the land better? How can we make land } \\
\text { available for young farmers that want to establish themselves in } \\
\text { the region? }\end{array}$ & & & & & & & & & & & & & & & \\
\hline $\begin{array}{l}\text { 8. How can we preserve plots of land that are suitable for agriculture } \\
\text { but are currently facing reforestation and abandonment? }\end{array}$ & & & & & & & & & & & & & & & \\
\hline
\end{tabular}


Figure 4 Land use and land cover scenarios

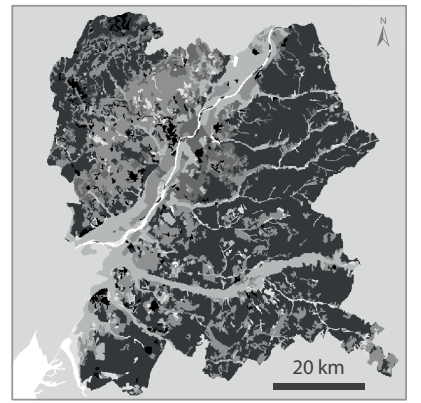

Land cover (2006)

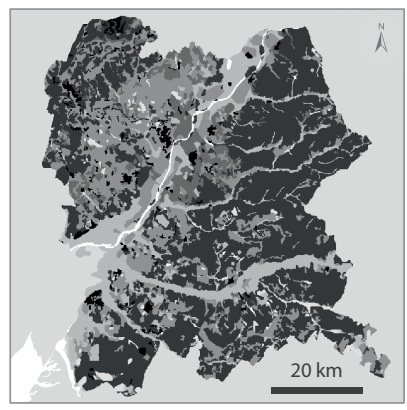

\begin{tabular}{|c|c|c|c|c|c|c|c|}
\hline \multicolumn{8}{|c|}{ Scenario 1: Business as usual } \\
\hline & 1 & 2 & 3 & 4 & 5 & 6 & 7 \\
\hline 1 & $100,0 \%$ & $0,0 \%$ & $0,0 \%$ & $0,0 \%$ & $0,0 \%$ & $0,0 \%$ & $0,0 \%$ \\
\hline 2 & $2,1 \%$ & $61,9 \%$ & $30,2 \%$ & $1,5 \%$ & $2,6 \%$ & $1,6 \%$ & $0,0 \%$ \\
\hline 3 & $0,5 \%$ & $0,0 \%$ & $90,9 \%$ & $1,2 \%$ & $4,4 \%$ & $2,9 \%$ & $0,0 \%$ \\
\hline 4 & $0,5 \%$ & $0,3 \%$ & $0,3 \%$ & $96,1 \%$ & $2,2 \%$ & $0,6 \%$ & $0,0 \%$ \\
\hline 5 & $0,3 \%$ & $0,2 \%$ & $0,3 \%$ & $0,3 \%$ & $97,9 \%$ & $1,1 \%$ & $0,0 \%$ \\
\hline 6 & $0,2 \%$ & $0,3 \%$ & $0,5 \%$ & $0,2 \%$ & $2,0 \%$ & $96,7 \%$ & $0,1 \%$ \\
\hline 7 & $0,0 \%$ & $0,0 \%$ & $0,8 \%$ & $0,0 \%$ & $0,9 \%$ & $0,6 \%$ & $97,6 \%$ \\
\hline
\end{tabular}

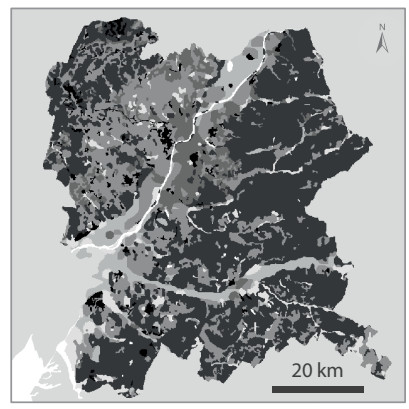

\begin{tabular}{|c|c|c|c|c|c|c|c|}
\hline \multicolumn{8}{|c|}{ Scenario 2: Climate change } \\
\hline & 1 & 2 & 3 & 4 & 5 & 6 & 7 \\
\hline 1 & $100,0 \%$ & $0,0 \%$ & $0,0 \%$ & $0,0 \%$ & $0,0 \%$ & $0,0 \%$ & $0,0 \%$ \\
\hline 2 & $2,0 \%$ & $95,5 \%$ & $0,0 \%$ & $1,1 \%$ & $1,8 \%$ & $1,6 \%$ & $0,0 \%$ \\
\hline 3 & $0,6 \%$ & $12,6 \%$ & $50,6 \%$ & $10,5 \%$ & $13,9 \%$ & $11,3 \%$ & $0,6 \%$ \\
\hline 4 & $0,5 \%$ & $0,3 \%$ & $0,0 \%$ & $96,5 \%$ & $2,1 \%$ & $0,6 \%$ & $0,0 \%$ \\
\hline 5 & $0,3 \%$ & $0,3 \%$ & $0,1 \%$ & $0,3 \%$ & $97,9 \%$ & $1,2 \%$ & $0,0 \%$ \\
\hline 6 & $0,2 \%$ & $0,4 \%$ & $0,1 \%$ & $0,2 \%$ & $2,1 \%$ & $96,8 \%$ & $0,1 \%$ \\
\hline 7 & $0,0 \%$ & $0,1 \%$ & $0,3 \%$ & $0,0 \%$ & $0,9 \%$ & $0,9 \%$ & $97,7 \%$ \\
\hline
\end{tabular}

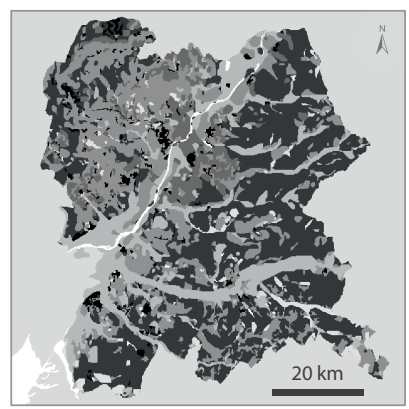

Artificial surface

Forest and seminatural areas

Permanent crops

Heterogeneous agricultural areas

Permanently irrigated land

Non-irrigated arable land and Pastures

Wetlands

Portugal

Conception: Abrantes and Fontes, 2015 Source: DGT, 2006

\begin{tabular}{|c|c|c|c|c|c|c|c|}
\hline & 1 & 2 & 3 & 4 & 5 & 6 & 7 \\
\hline 1 & $100,0 \%$ & $0,0 \%$ & $0,0 \%$ & $0,0 \%$ & $0,0 \%$ & $0,0 \%$ & $0,0 \%$ \\
\hline 2 & $2,1 \%$ & $63,4 \%$ & $29,0 \%$ & $1,5 \%$ & $2,7 \%$ & $1,3 \%$ & $0,0 \%$ \\
\hline 3 & $0,5 \%$ & $0,0 \%$ & $92,1 \%$ & $1,2 \%$ & $4,4 \%$ & $1,8 \%$ & $0,0 \%$ \\
\hline 4 & $0,5 \%$ & $0,3 \%$ & $0,3 \%$ & $96,4 \%$ & $2,1 \%$ & $0,2 \%$ & $0,0 \%$ \\
\hline 5 & $0,3 \%$ & $0,2 \%$ & $0,3 \%$ & $0,3 \%$ & $98,4 \%$ & $0,5 \%$ & $0,0 \%$ \\
\hline 6 & $0,2 \%$ & $1,1 \%$ & $4,2 \%$ & $2,7 \%$ & $10,7 \%$ & $81,0 \%$ & $0,1 \%$ \\
\hline 7 & $0,0 \%$ & $0,0 \%$ & $0,8 \%$ & $0,0 \%$ & $1,0 \%$ & $0,6 \%$ & $97,6 \%$ \\
\hline
\end{tabular}

\section{Discussion}

The interviews that enabled the researchers to extract key questions, together with the two workshops on the topic "The future of agriculture in our area, problems and prospects" and the ongoing scenario building and discussion are contributing to a fresh perspective on local/regional agriculture and its future. From this point of view, this constituted an 
original geoprospective exercise that was: 1) territorially "localized" (i.e., it was placed in the context of the work and daily lives of the actors mobilized) (Lardon et al., 2010). The method was therefore based on the famers' personal experiences regarding their social and professional circumstances given the dynamics that affect their areas and activities. The method also incorporated politicians' and technicians' skills and experiences regarding territorial policy. 2) "Exploratory": a) in linking action and research, since from the start it was built on the basis of collaboration between stakeholders and academics, which helped the debate on different development perspectives and integrating possible distinctive reflections for the future; b) in using and integrating GI and spatial analysis in a participative way (e.g., scenarios building and exploration).

This geoprospective exercise also enabled us to learn some lessons for future research and action. The main limitations of this research came from the low attendance to the workshops when compared, for instance, with the total number of farmers in the selected areas and with the number of interviewees. From the perspective of the number of contacts that were made, this does not match what was expected, especially in Almeirim, where the recruitment process was broader. Some reasons can explain the low attendance rate to both workshops. In Almeirim, we hypothesize that the release was made mostly at an institutional level and therefore it did not reach everyone. Even if the mayor knows the farmers, apparently he did not have a strong mobilizing capacity or a high social capital among the farmers, which leads us to think that the recruitment of participants for the workshops should probably have been carried out with the support of the associated agriculture bodies, together with their associates. Besides, this workshop took place at the height of the harvest season, under heavy rain and a storm. At Achete (Santarém), the small number of participants could be related with the workshop room booking and the recruitment process that was started too late (two weeks before the event). Some farmers did not receive the letter of invitation on time. The weak attendance to Achete's workshop could also be a result of the isolated location of the room where it took place.

The approach itself may also be criticized and blamed for the poor attendance to the workshops. Much more likely is that the subject of the research was not sufficiently attractive to justify the farmers leaving their daily routines, as the period chosen for the workshops was unfavourable for them. This can therefore be another explanatory element of the weak participation in the meetings: a hardly interesting agenda in a disadvantageous time frame. But there is also the possibility that university studies are perceived as unattractive, as they have nothing to offer that can interest farmers. If so, this confirms the usual gap between academia and practitioners. In spite of the few participants in the workshops, the content and the knowledge generated during the debate were very good. There was a convergence in the opinions about the concerns (among themselves) and agreement regarding the problems, challenges and questions presented by the researchers. In general, all those involved in the debate interacted and contributed to a final synthesis with concrete proposals.

Consequently, we consider that this approach reinforced research and action. In fact, the researchers' interactions with the participants resulted in some exchanges as the director and producer of the wine cooperative (Almeirim) and representative of the regional office of agriculture showed a willingness to collaborate in further team initiatives. In fact, these workshops were particularly marked by the development of new relationships. Indeed, the Ministry of Agriculture (public administration) offered a partnership with the researchers to prepare a future regional seminar. Taking advantage of this willingness to actively participate in future work between researchers and stakeholders, the research was extended and three solid prospective land use scenarios were built and are being 
discussed with the aim of ascertaining whether the proposed solutions and visions of the stakeholders were feasible in the territory. It allowed us to identify territories that are vulnerable and at risk so as to help to anticipate problems and changes and foster more prospective participation. These land use scenarios are being presented individually to the stakeholders. They responded with interest, but also with some divergent positions, namely questioning the methods used, which lead us to consider the difficulty of communicating GI and spatial analysis methods to stakeholders.

\section{Conclusions}

This paper explored PAR, taking into account spatial structures and dynamics of the peri-urban agricultural region of Lezíria do Tejo; engaging communities, stakeholders, researchers and policy-makers, in a particular co-production process that affect their lives in a desired and shared future. The prospective handled in this research used a hybrid approach (qualitative and quantitative methods) to anticipate the possible changes in agriculture and land use. The goal of this geoprospective and PAR supported by GI was therefore to inform practice while contributing to the academic knowledge on the topic of threats to sustainable agriculture in peri-urban areas. It was developed in four-steps: 1) providing GI to select stakeholders' interview sites; 2) using interviews to identify problems and challenges (e.g., farmland disappearing) and create a bond with the stakeholders; 3 ) adopting participatory prospective workshops to debate questions raised in the interviews and find common solutions for long-term agricultural sustainability in the region; 4) building land use scenarios to help anticipate problems and foster more participative spatial planning and rural development policies for the future.

The results of both the interviews and the workshops were very fruitful as the stakeholders presented solutions for several questions, so there is evidence that these methods were a way to raise critical thinking among participants as Table 2 synthesizes. Also, this alternative research revealed a comprehensive understanding of the spatial dynamics in the social context, which engaged everyone within it. But the results also highlight tensions between participants, thus a stronger relationship and commitment between local stakeholders, namely between farmers and policy-makers, should be achieved. The workshops revealed a systematic and transversal lack of relation and a general distrust between the stakeholders, uncovering evidence of different power relations. Working collaboratively within local communities helps to bring about possible directions for shared futures and changes in power relations. It also empowers participants by fostering consciousness of their practices, which facilitates a shared feeling of equity. Additionally, it can act as a stimulus for their social and professional transformation.

From a research perspective, this participatory approach that linked researchers and local stakeholders was also very significant as it helped to bridge the gap between farmers, policy-makers, practitioners and academia. Moreover, it addresses the complexity of the real world through a reflective process. As a result, this has originated ideas and regional and local cohesion projects in that territory in a perspective that takes into account geospatial data to support common solutions for the future. This research demonstrates that understanding what motivates stakeholders to commit to and enact change may make implementing research into practice more successful in the future.

\section{Acknowlegments}

This paper was developed in the context of the DAUME project (ANR-2010STRA-007-01) and of the Agrimet-Mod project (PTDC/ATP-EUR/4910/2012). 


\section{Bibliography}

ABELAIRAS-ETXEBARRIA, Patricia and ASTORKIZA, Inma (2012) Farmland prices and land-use changes in periurban protected natural areas. Land Use Policy, vol. 29, n³ 3 p. 674-683.

ABRANTES, Patrícia, FONTES, Inês, GOMES, Eduardo and ROCHA, Jorge (2016) Compliance of land cover changes with municipal land use planning: Evidence from the Lisbon metropolitan region (1990-2007). Land Use Policy, vol. 51, p. 120-134.

ABRANTES, Patrícia, MARQUES DA COSTA, Eduarda, QUEIRÓS, Margarida, PADEIRO, Miguel and MOUSSELIN Guilhem (2013) Lezíria do Tejo: agriculture et étalement urbain aux marges métropolitaines de Lisbonne. Cahiers Agricultures, vol.22, $n^{\circ} 6$, p. 526-534.

ABRANTES, Patrícia, QUEIRÓS, Margarida, MARQUES DA COSTA, Eduarda, MORGADO, Paulo and GOMES, Eduardo (2012) Geographic social network analysis through graph-based model and GIS: An application to the Lezíria do Tejo Region (Portugal). American Association of Geographers Annual Meeting, New York, February 24-28 2012.

ANR (THE FRENCH NATIONAL RESEARCH AGENCY) (2010) Écosystèmes, territoires, ressourcesvivantes et agriculture (SYSTERRA) 2010 Projet DAUME: Sustainability of urban agricultures in the Mediteranean area [Online]. http://www.agence-nationalerecherche.fr/?Project=ANR-10-STRA-0007

BALEZ, Anna and REUNKRILERK, Juliette (2013) Écosystèmes et territoires urbains: impossible conciliation? Développement durable et territoires, vol. 4, no2 [Online]. https:// developpementdurable.revues.org/9853

BJÖRKLUND, Johanna, EKSVÄRD, Karin and SCHAFFER, Christina (2014) Assessing ecosystem services in perennial intercropping systems: Participatory action research in Swedish modern agroforest. The $11^{\text {th }}$ European International Farming System Association Group Symposium, Berlin, April 1-4 2014, p. 112-113.
BONARD, Yves (2006) Enjeux et limites de la concertation en aménagement du territoire. Urbia - Les Cahiers du développement urbain durable, vol.3, p. 95-111.

BOURGEOIS, Robin (2013) The state of foresight in food and agriculture: Challenges for impact and participation. European International Foresight Academy Academic Seminar - Participatory foresight for smarter futures: From design to impact, Zurich, September 16-19 2014.

BROWN, Greg, MONTAG, Jessica and LYON, Katie (2012) Public participation GIS: A method for identifying ecosystem services. Society \& Natural Resources, vol. 25, no 7, p. 633-651.

DARRÉ, Jean-Pierre (2006) La recherche coactive de solutions entre agents de développement et agriculteurs. Paris, Éditions du Gret.

DEBARBIEUX, Bernard and LARDON, Sylvie (2003) Les figures du projet territorial. La Tour d'Aigues, Éditions de l'Aube.

DE JOUVENEL, Hugues (2004) Invitation à la prospective/An invitation to foresight. Paris, Futuribles.

DGT (DIREÇÃO-GERAL DO TERRITÓRIO) (2006) Mapa CORINE Land Cover: CLC2006 [Online]. http://www. dgterritorio.pt/cartografia_e_geodesia/ cartografia/cartografia_tematica/ corine_land_cover_clc_/

DGT (DIREÇÃO-GERAL DO TERRITÓRIO) (2015) Carta Administrativa Oficial de Portugal: Versão 2015 [Online]. http://www. dgterritorio.pt/cartografia_e_geodesia/ cartografia/carta_administrativa_oficial_ de_portugal_caop_/caop_download_/ carta_administrativa_oficial_de_portugal versao_2015_2/

ELWOOD, Sarah (2006) Critical issues in participatory GIS: Deconstructions, reconstructions, and new research directions. Transactions in GIS, vol. 10, no5, p. 693-708.

EEA (European Environment Agency) (2006) Urban sprawl in Europe - The ignored challenge. EEA Report no 10. Copenhagen, Office for Official Publications of the European Communities. 
FLETCHER, Amber J., MACPHEE, Maura and DICKSON, Graham (2015) Doing participatory action research in a multicase study: A methodological example. International Journal of Qualitative Methods, vol. 14, n5, p. 1-9.

GODET, Michel (2001) Creating futures: Scenario planning as a strategic management tool. Paris, Economica.

GODET, Michel (2005) Strategic foresight - La prospective - Use and misuse of scenario building. LIPSOR Working Paper, $\mathrm{n}^{\circ}$ 10, p. 1-143.

GOURMELON, Françoise, HOUET, Thomas, VOIRON-CANICIO, Christine and JOLIVEAU, Thierry (2012) La géoprospective, apport des approches spatiales à la prospective. L'Espace géographique, vol.2, n41, p. 97-98.

GRÉMONT, Marine and HOUET, Thomas (2015) Downscaling socio-economic prospective scenarios with a participatory approach for assessing the possible impacts of future land use and cover changes on the vulnerability of societies to mountain risks. European Geosciences Union 2015 General Assembly, Vienna, April 12-17 2015.

HEWITT, Richard, VAN DELDEN, Hedwig and ESCOBAR, Francisco (2014) Participatory land use modelling, pathways to an integrated approach. Environmental Modelling \& Software, vol. 52, p. 149-165.

HOUET, Thomas and GOURMELON Françoise (2014) La géoprospective Apport de la dimension spatiale aux démarches prospectives. Cybergeo: revue européenne de géographie [Online]. https://cybergeo.revues.org/26194

HUNG, Hung-Chih, YANG, Ching-Yi, CHIEN, Chang-Yi and LIU, Yi-Chung (2016) Building resilience: Mainstreaming community participation into integrated assessment of resilience to climatic hazards in metropolitan land use management. Land Use Policy, vol. 50, p. 48-58.

INE (INSTITUTO NACIONAL DEESTATÍSTICAPORTUGAL) (1999) Receseamento Agrícola 1999 [Online]. http://ra09.ine.pt/xportal/ xmain?xpid=RA2009\&xpgid=ine_ra2009_ publicacao_det\&contexto=pu\&PUBLICACOESpub_boui $=5596032 \&$ PUBLICACOESmodo=2\&selTab=tab1 \&pra2009=77999466
INE (INSTITUTO NACIONALDEESTATÍSTICAPORTUGAL) (2009) Receseamento Agrícola 2009 [Online]. http://ra09.ine.pt/xportal/ xmain?xpgid=ra_home\&xpid=RA2009

INE (INSTITUTO NACIONAL DE ESTATÍSTICA - PORTUGAL) (2011) Censos 2011 Resultados Definitivos - Portugal: XV Recenseamento Geral da População. $V$ Recenseamento Geral da Habitação. Lisbon, Instituto Nacional de Estatística.

INRA (FRENCH NATIONAL INSTITUTE FOR AGRICULTURAL RESEARCH) (2011) Daume:Durabilitédes Agricultures Urbaines en Méditérranée [Online]. http://www1. montpellier.inra.fr/daume/?p=2\&t=project

KATOPPO, Martin L. and SUDRADJAT, Iwan (2015) Combining Participatory Action Research (PAR) and Design Thinking (DT) as an alternative research method in architecture. Procedia - Social and Behavioral Sciences, vol. 184, p. 118-125.

KINDON, Sara (2010) Participation. In Susan J. Smith, Rachel Pain, Sallie A. Marston and John Paul Jones III (eds.) The SAGE Handbook of Social Geographies. London, SAGE Publishing, p. 517-545.

LARDON, Sylvie, ANGEON, Valérie, LEBLANC, Patrice and TROGNON, Laurent (2010) Usage du «jeu de territoire» pour faciliter la construction d'une vision partagée du territoire dans une démarche participative. In Daniel Ricard (ed.) Développement durable des territoires: de la mobilisation des acteurs aux démarches participatives. Clermont-Ferrand, Presses Universitaires Blaise Pascal, p. 129-145.

LECK, Hayley and SIMON, David (2013) Fostering multiscalar collaboration and co-operation for effective governance of climate change adaptation. Urban Studies, vol. 50, n6, p. 1221-1238.

MASON, Kelvin (2015) Participatory action research: Coproduction, governance and Care. Geography Compass, vol.9, nº 9 , p. 497-507.

MERCIER, Guy, SIMARD, Martine and CÔTÉ, Michel (2014) L'urbanisation diffuse: un difficile mais inévitable défi d'aménagement. Cahiers de géographie du Québec, vol. 58, nº 165, p. 323-327. 
MORGADO, Paulo, GOMES, Eduardo, COSTA, Nuno (2014) Competing visions? Simulating alternative coastal futures using a GISANN web application. Ocean \& Coastal Management, vol. 101, p. 79-88.

OGILVY, James A. (2002) Creating better futures: Scenario planning as a tool for a better tomorrow. Oxford, Oxford University Press.

PADEIRO, Miguel (2015) Os factores determinantes da edificação recente na AML. Finisterra, vol. 50, no 99, p. 5-29.

PINTO, Ana Julia (2011) A participação cidadã no processo de planeamento municipal em Portugal. On the waterfront, $n^{\circ} 18$, p. 17-46.

POULOT, Monique (2008) Les territoires périurbains : "fin de partie» pour la géographie rurale ou nouvelles perspectives. Géocarrefour, vol. 83, nº4, p. 269-278.

POWER, Alison G. (2010) Ecosystem services and agriculture: Tradeoffs and synergies. Philosophical Transactions of The Royal Society B Biological Sciences, vol.365, no 1554 , p. 2959-2971.

QUEIRÓS, Margarida (2007) Agenda 21 Local: Auto-organização, cooperação e inteligência descentralizada. Finisterra, vol. $42, \mathrm{n}^{\circ} 83$, p. 65-77.

RUAULT, Claire (1996) L'invention collective de l'action: initiatives de groupes d'agriculteurs et développement local. Paris, L'Harmattan.

SOULARD, Christophe, BANZO, Mayté, PERRIN, Coline and VALETTE, Élodie (2015) Urban strategies and practices for agriculture and food: Six Mediterranean case studies. The $2^{\text {nd }}$ International Conference on Agriculture in an Urbanizing Society - Reconnecting agriculture and food chains to societal needs, Rome, September 14-17 2015.

SUTHERLAND, William J., ARMSTRONGBROWN, Susan, ARMSWORTH, Paul R., BRERETON, Tom, BRICKLAND, Jonathan, CAMPBELL, Colin D. et al. (2006) The identification of 100 ecological questions of high policy relevance in the UK. Journal of Applied Ecology, vol.43, n 4 , p. 617-627.
VALETTE, Élodie, PERRIN, Colineand SOULARD, Christophe (2012) Sustainable cities vs sustainable agricultures. A scientific project on agro-urban systems, North and South of the Mediterranean. International Conference on Multifunctional Agriculture and UrbanRural Relations: Agriculture in an urbanizing society, Wageningen, April 1-4 2012.

VANDERMEULEN, Valerie, VERSPECHT Ann, VAN HUYLENBROECK, MEERT, Henk, BOULANGER, Ankatrien and VAN HECKE, Etienne (2006) The importance of the institutional environment on multifunctional farming systems in the peri-urban area of Brussels. Land Use Policy, vol.23, no4, p. 486-501.

VAN ZANTEN, Boris, VERBURG, Peter H., ESPINOSA, Maria, GOMEZ-Y-PALOMA, Sergio, GALIMBERTI, Giuliano et al. (2014) European agricultural landscapes, common agricultural policy and ecosystem services: A review. Agronomy for Sustainable Development, vol.34, n², p. 309-325.

VERMEULEN, Sonja, ZOUGMORÉ Robert, WOLLENBERG, Eva, THORNTON, Philip, NELSON, Gerald, KRISTJANSON, Patricia, KINYANGI, James, JARVIS, Andrew, HANSEN, James, CHALLINOR, Andrew, CAMPBELL, Bruce and AGGARWAL, Pramog (2012) Climate change, agriculture and food security: A global partnership to link research and action for low-income agricultural producers and consumers. Current Opinion in Environmental Sustainability, vol.4, p. 128-133.

VOIRON-CANICIO, Christine and LIZIARD, Sophie (2015) Anticipating the future of the Mediterranean coastal regions through geoprospective approaches: The Latin Arc's coastal areas and the region of Nice. In Theano S. Terkenli, Annick Douguedroit and Louis F. Cassar (eds.) (2015) Connections, mobilities, urban prospects and environmental threats: The Mediterranean in transition. Cambridge, Scholars Publishing, p. 51-76.

VOLKERY, Axel, RIBEIRO, Teresa, HENRICHS, Thomas and HOOGEVEEN, Ybele (2008) Your vision or my model? Lessons from participatory land use scenario development on a European scale. Systemic Practice and Action Research, vol.21, nº6, p. 459-477. 